\title{
WORKSHOP PEMANFAATAN MARKET PLACE DALAM MENUNJANG PEMASARAN PRODUK PADA KOMUNITAS MERSI FANS CLUB DIMASA PANDEMIK COVID-19
}

\author{
Frieyadie 1; Nurajijah 2; Fachri Amsury ${ }^{3}$; Daning Nur Sulistyowati ${ }^{4}$; Siti Fauziah ${ }^{5}$ \\ Program Studi Teknik Informatika \\ Sekolah Tinggi Manajemen Informatika dan Komputer Nusa Mandiri \\ Jl. Jatiwaringin Raya No.02, Kecamatan Makasar Jakarta Timur \\ 17rieyadie@nusamandiri.ac.id, 2nurajijah.nja@nusamandiri.ac.id, ${ }^{3}$ fachri.fcy@nusamandiri.ac.id, \\ ${ }^{4}$ daningnur.dgs@nusamandiri.ac.id, ${ }^{5}$ siti.suz@nusamandiri.ac.id
}

\begin{abstract}
PT Radio Swara Mersidiona or better known as Radio MeRsi which is trusted in the world of broadcasting, always gives listeners satisfaction. Since 1971 Mersi radio has remained consistent in the music that is presented, namely dangdut so that it has many loyal fans so that a community called Mersi Fans Club (MFC) is formed. The problems faced by the Mersi Fans Club (MFC) community include members of the Mersi Fans Club Community, who do not really understand how to use the market place in supporting product marketing. Not yet able to implement their product marketing on the Market Place. Also during the Covid-19 pandemic, face-to-face activities were also an obstacle to violating health protocols. As a solution to this community service activity by holding online workshops using the Zoom meeting facility. The results of this activity are expected to be able to understand by continuing to try and practice what has been obtained, as well as by opening communication with the WA Group .
\end{abstract}

Keywords: Workshop, Marketplace, Product Marketing

\begin{abstract}
Abstrak
PT Radio Swara Mersidiona atau yang lebih dikenal dengan nama Radio MeRsi yang dipercaya dalam dunia penyiaran, selalu memberikan kepuasan bagi pendengar. Sejak tahun 1971 radio mersi tetap konsisten dalam musik yang disugukan yaitu dangdut sehingga memiliki banyak penggemar setia sehingga terbentuklah komunitas yang bernama Mersi Fans Club (MFC). Permasalahan yang dihadapi oleh komunitas Mersi Fans Club (MFC) diantaranya para anggota Komunitas Mersi Fans Club l belum terlalu memahami bagaimana Pemanfaatan Market Place Dalam Menunjang Pemasaran Produk. Belum dapat mengimplementasikan pemasaran produk mereka pada Market Place. Juga dimasa pademik Covid-19 ini, kegiatan tatap muka juga menjadi kendala melanggar protokol kesehatan. Sebagai solusi kegiatan pengabdian masyarakat ini dengan mengadakan kegiatan Workshop secara daring dengan menggunakan fasilitas Zoom meeting. Hasil dari kegiatan ini, diharapkan dapat memahami dengan terus menurus dicoba dan mempraktekan yang sudah didapatkan, sekaligus dengan membuka komunkasi dengan WA Group.
\end{abstract}

Kata Kunci: Workshop, Marketplace, Pemasaran Produk

\section{PENDAHULUAN}

Kemajuan dan perkembangan dalam penggunaan perangkat keras dikehidupan seharihari membawa kita dalam kehidupan yang maju. Keahlian dan kemampuan diri memiliki dampak yang baik untuk membantu menyelesaikan pekerjaan-pekerjaan manusia. Bagi seorang dosen kegiatan Tridharma Perguruan Tinggi yang wajib dilaksanakan setiap Perguruan Tinggi adalah Pendidikan, Penelitian, dan Pengabdian Masyarakat.
Dimasa pandemic Covid-19 global ini menimbulkan krisis kesehatan [1] yang mengkhawatirkan yang berakibat berdampak pada berdampak pada perekonomian [2]. Dampak yang dirasakan yaitu laju pertumbuhan ekomoni memang sangatlan melambat sehingga segala aspek ikut berdampak buruk. Perekonomian masyarakat mengalami penurunan bahkan anjlok, banyak pengusaha, pedagang, mengalami kerugian bahkan tidak dapat beroperasi lagi [3]. Karena keadaan saat ini, masyarakat dan UMKM lokal belum siap menghadapi krisis, sehingga 
pendapatan penjualannya menurun atau bahkan tidak dapat beroperasi [4].

Dari kondisi ini, akademisi STMIK Nusa Mandiri mengadakan kegiatan pengabdian masyarakat untuk mendorong dan berbagi pengalaman ke Komunitas Mersi Fans Club, untuk dapat meningkatkan kegiatan usaha bagi anggotanya. Pelaksaan kegiatan pengabdian masyarakat secara daring menggunakan fasilitas zoom meeting

Berdasarkan informasi yang diperoleh dari Komunitas Mersi Fanc Club, beberapa masalah yang dihadapi dapat diidentifikasikan bahwa para Komunitas Mersi Fans Club I belum terlalu memahami bagaimana Pemanfaatan Market Place Dalam Menunjang Pemasaran Produk, dan anggota Komunitas Mersi Fans Club belum dapat mengimplementasikan pemasaran produk mereka pada Market Place.

Sebagai solusi menaggapi masalah yang dihadapi Komunitas Mersi Fans Club, dengan pendekatan Pelatihan dengan pendampingan, supaya para Komunitas Mersi Fans Club lebih fokus memahami materi Pemanfaatan Market Place Dalam Menunjang Pemasaran Produk tersebut. Market Place Dalam Menunjang Pemasaran Produk yang akan digunakan untuk kegiatan tersebut adalah Tokopedia

Tujuan dari pengabdian ini agar para anggota Komunitas Mersi Fans Club memiliki kemampuan memasarkan produk komunitas dengan memanfaatkan marketplace dalam menghadapi era 4.0.

\section{METODE PENGABDIAN MASYARAKAT}

\section{Bentuk Kegiatan}

Pengabdian kepada masyarakat yang diberikan berupa Workshop Online bagaimana Pemanfaatan Market Place Dalam Menunjang Pemasaran Produk bagi Komunitas Mersi Fans Club. Teknik yang digunakan dalam menyampaikan materi pelatihan adalah workshop online dengan menggunakan alat bantu yaitu aplikasi Zoom dengan cara sharescreen materi Pemanfaatan Market Place Dalam Menunjang Pemasaran Produk.

\section{Pelaksanaan}

Pengabdian Masyarakat di selenggarakan via aplikasi Zoom, yang dilaksanakan pada hari minggu, tanggal 19 April 2020.

\section{Tahapan Kegiatan}

Tahapan kegiatan pengabdian masyarakat yang dilaksanakan tertian pada tahapan pengabdian masyarakat pada Gambar 1.

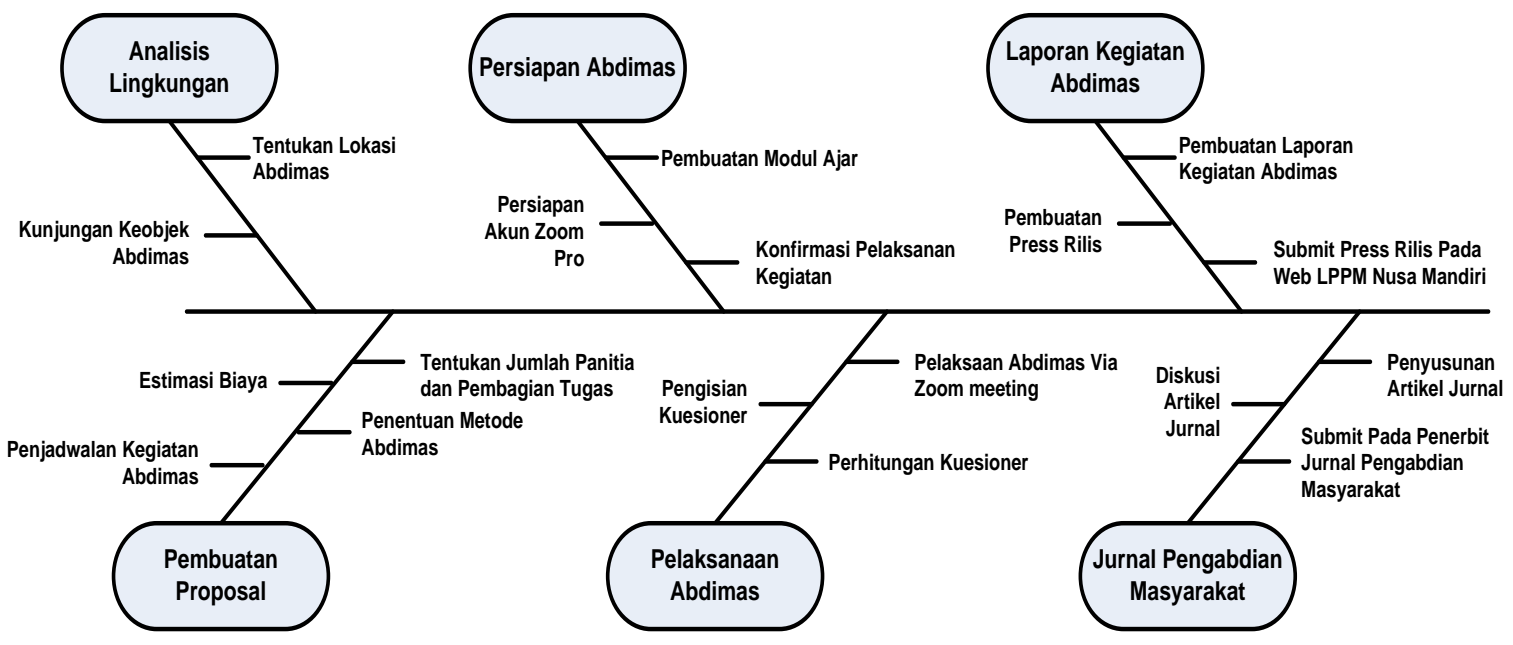

Gambar 1. Tahapan Pengabdian Masyarakat

Penjelasan tahapan kegatan pengabdian masyarakat sebagai berikut.

1. Analisis Lingkungan

Analisis lingkungan dimaksudkan sebagai kegiatan penentuan lokasi ke objek pelaksanaan pengabdian masyarakat. Objek yang dituju adalah Komunitas Mersi Fans Club.

2. Pembuatan Proposal

Pembuatan proposal, meliputi penentuan estimasi biaya, dimana pembiayaan ini sangat 
penting, dikarenakan harus mealokasikan biaya untuk kebutuhan pengabdian masyarkat. Penentuan jumlah panitia dan peserta yang ikut dalam kegiatan abdimas ini. Penentuan metode yang pas untuk kegiatan abdimas. Penjadwalan kegiatan abdimas harus pas waktunya mengingat kegiatan abdimas dilakukan secara daring dengan menggunakan via zoom, supaya peserta dari Komunitas Mersi Fans Club bisa ikut semua.

3. Persiapan Abdimas

Persiapan abdimas ini meliputi pembuatan modul ajar sesuai dengan yang disepakati dengan Komunitas Mersi Fans Club. Persiapan pembelian akun zoom meeting yang bisa digunakan secara baik.

4. Pelaksanaan Abdimas

Pelaksanaan abdimas ini audiens adalah anggota Komunitas Mersi Fans Club, melakukan kegiatan ini melalui via zoom meeting yang lakukan dari rumah masingmasing anggota, begitu juga dengan panitia pelaksana. Setelah kegiatan pelatihan selesai, para peserta Komunitas Mersi Fans Club mengisi kuesioner secara online yang dibuat menggunakan google form.

5. Laporan Kegiatan Abdimas

Laporan kegiatan merupkan bentuk pertanggung jawaban kegiatan yang telah dilaksankan. Laporan tersebut meliput laporan kegiatan pengabdian masyarakat, termasuk laporan keuangan. Pembuatan press rilis kegiatan yang bisa diunggah pada website umum agar bisa dibaca oleh masyarakat luat.

6. Jurnal Pengabdian Masyarakat

Pembuatan jurnal pengabdian masyarakat merupakan opsi tambahan luaran dari kegiatan pengabdian masyarakat

Pelaksaan pelatihan ini mengunakan metode ceramah plus [5] dengan ditunjang diskusi, tanya jawan dan demonstrasi.

\section{Pengukuran}

Pengukuran hasil kuesioner dari peserta anggota Komunitas Mersi Fans Club dengan menggunakan skala Likert. Sekala likert ini biasa digunakan untuk mengukur sikap, pendapat dan persepsi seseorang [6].

\section{a. Validitas}

Validitas merupakan pengujian ketepatan dan kebenaran suatu instrument. Apabila hasil perhitungan dinyatakan valid maka instrument yang diuji adalah benar.

$$
r=\frac{n \sum X Y-\left(\sum X\right)\left(\sum Y\right)}{\sqrt{\left(n \sum(X)^{2}-\left(\sum X\right)^{2}\right)\left(n \sum(Y)^{2}-\left(\sum Y\right)^{2}\right)}}
$$

dimana $: r=$ rxy $=$ koefisien korelasi $\mathrm{N}=$ jumlah responden uji coba $\mathrm{X}=$ skor tiap item $\mathrm{Y}=$ skor seluruh item responden uji coba.

$t_{\text {hitung }}=\frac{r_{x y} \sqrt{(n-2)}}{\sqrt{\left(1-r_{x y^{2}}\right)}}$

Nilai n diisi dengan jumlah responden instrumen dalam angket, jumlah responden sebanyak 23 responden

\section{b. Reablitas}

Reabiltas merupakan penujian kepercayaan dan kehandalan, apabila hasil hitungan dinyatakan valid, maka penelitian nyatakan dipercaya. Pengabdian masyarakat ini menggunakan rumus Alpha Cronbach untuk menguji reliabilitas instrumen, karena instrumen penelitian menggunakan bentuk angket dan skala hirarkis. Rumus Alpha Cronbach adalah sebagai berikut:

$r_{11}=\left(\frac{n}{n-1}\right)\left(1-\frac{\sum \sigma_{t}^{2}}{\sigma_{t}^{2}}\right)$

\section{HASIL DAN PEMBAHASAN}

Belajar bertujuan mengubah perilaku sebagai hasil dari ilmu dan pengalaman yang di dapat dari interaksi seseorang dengan lingkungannya [7].

\section{Pelaksanaan Kegiatan}

Kegiatan pelatihan dimulai dengan pembukaan dan dilanjut dengan materi penyampaian oleh tutor dan tidak lupa tiap peserta diberikan materi yang sama dengan tutor.
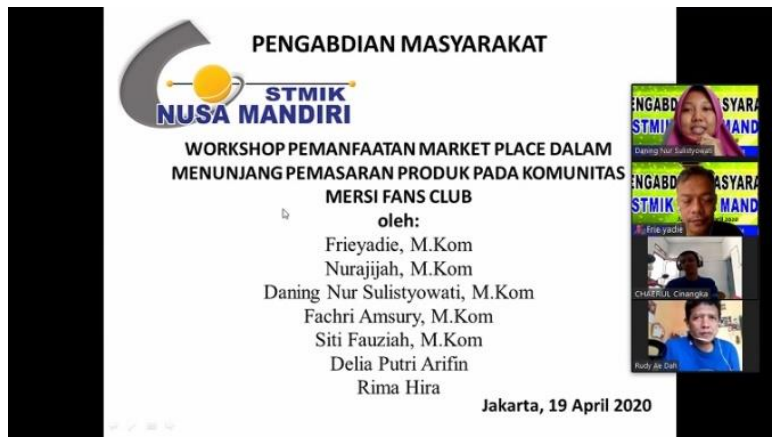

Gambar 1. Pembukaan Materi

Pada gambar 1 merupakan pembukaan materi workshop pemanfaatan marketplace dalam menunjang pemasaran produk pada komunitas mersi fans club 

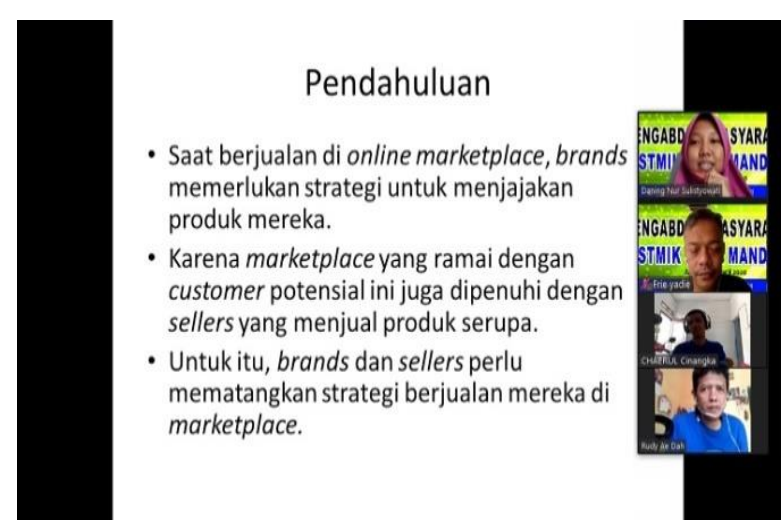

Gambar 2. Tutor menyampaikan materi

Pada gambar 2 tutor menyampaikan materi tpendahuluan workshop pemanfaatan marketplace dalam menunjang pemasaran produk pada komunitas mersi fans club.
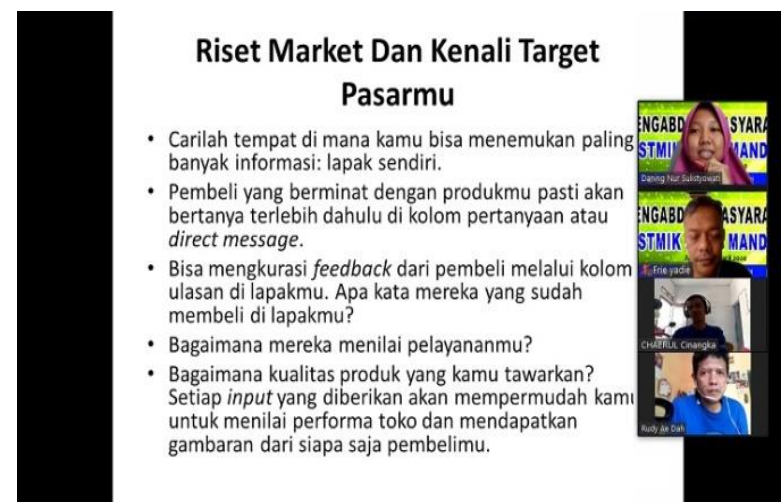

Gambar 3. Peserta mengajukan pertanyaan

Pada gambar 3 terlihat penyampaian materi mengenai muatan riset market dan kenali targe pasarmu. Dimana muatan materi untuk mencari tempat dimanan bisa menemukan paling banyak informasi untuk membuka usaha..

Pada sesi akhir, dilakukan foto bersama seperti yang terlihat pada gambar 4 .

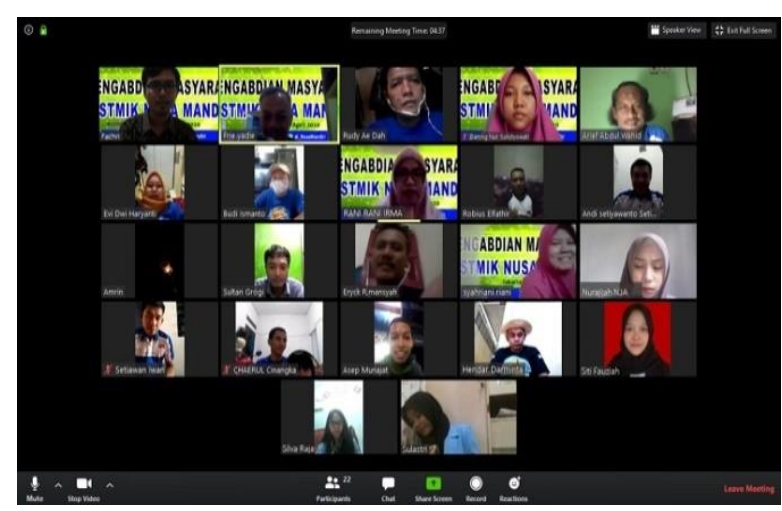

Gambar 4. Sesi foto
Peserta mendapatkan ilmu baru serta tips dan trik untuk pemanfaatan marketplace dalam menunjang pemasaran produk. Para peserta dari Komunitas Mersi Fans Club pada pelatihan ini memberikan respon melalu kuesioner yang disebarkan via online guna untuk mendapat respon atas pelaksanaan pelatihan dengan total responden sebanyak 23 orang.

Terdapat 6 (enam) pertanyaan didalam kuesioner yang harus diisikan oleh responden.

1. Personil/anggota yang terlibat dalam kegiatan pengabdian masyarakat memberikan pelayanan sesuai dengan kebutuhan peserta (P1)

2. Tutor menyampaikan materi kegiatan dengan jelas dan mudah dimengerti oleh peserta (P2)

3. Materi yang disampaikan sesuai dengan kebutuhan peserta dalam menambah wawasan, pengetahuan, keterampilan dan keahlian peserta (P3)

4. Peralatan untuk menyampaikan materi memadai (P4)

5. Kegiatan pengabdian masyarakat yang disampaikan bermanfaat untuk menambah wawasan, pengetahuan, keterampilan dan keahlian peserta (P5)

6. Layanan Internet berupa kuota tersedia dengan baik (P6)

\section{Monitoring dan Evaluasi}

Tahap selanjutnya adalah melakukan kegiatan monitor dan evaluasi dari kegiatan Pengabdian Masyarakat. Evaluasi berupa pengisian kuesioner dan pengujiannya menggunakan pengujian validitas dan reabilitas.

\section{a. Pengujian Validitas}

Berikut hasil pengujian validitas dari kuesioner yang diisikan oleh peserta.

Tabel 1. Hasil Uji Validitas

\begin{tabular}{cccc} 
Responden & rxy & t-hitung & Keterangan \\
\hline R1 & 0,84 & 7,11 & Valid \\
\hline R2 & 0,64 & 3,87 & Valid \\
\hline R3 & 0,64 & 3,87 & Valid \\
\hline R4 & 0,64 & 3,87 & Valid \\
\hline R5 & 0,85 & 7,48 & Valid \\
\hline R6 & 0,49 & 2,55 & Valid \\
\hline R7 & 0,56 & 3,08 & Valid \\
\hline R8 & 0,97 & 19,92 & Valid \\
\hline R9 & 0,84 & 7,16 & Valid \\
\hline R10 & 0,93 & 11,79 & Valid \\
\hline R11 & 0,49 & 2,55 & Valid \\
\hline R12 & 0,71 & 4,58 & Valid \\
\hline R13 & 0,49 & 2,55 & Valid \\
\hline R14 & 0,84 & 6,99 & Valid \\
\hline
\end{tabular}




\begin{tabular}{cccc}
\hline Responden & rxy & t-hitung & Keterangan \\
\hline R15 & 0,49 & 2,55 & Valid \\
\hline R16 & 0,84 & 7,16 & Valid \\
\hline R17 & 0,84 & 7,16 & Valid \\
\hline R18 & 0,93 & 11,79 & Valid \\
\hline R19 & 0,76 & 5,28 & Valid \\
\hline R20 & 0,93 & 11,79 & Valid \\
\hline R21 & 0,50 & 2,65 & Valid \\
\hline R22 & 0,44 & 2,25 & Valid \\
\hline R23 & 0,93 & 11,79 & Valid \\
\hline
\end{tabular}

diskusi dan pertanyaan yang berkaitan dengan isi materi pembelajaran.

\section{KESIMPULAN}

Hasil dan luaran yang dicapai dalam pelaksanaan pengabdian masyarakat dengan materi pembelajaran teori dan praktek Pemanfaatan Market Place Dalam Menunjang Pemasaran Produk, diantaranya membangun peserta dengan kegiatan yang positif dan menambah pengetahuan

Hasil instrument yang diujikan pada Tabel 1. Semua pertanyaan dijawab sesuai dengan persepsi responden, kemudian dihitung didapatkan hasil yang dinyatakan valid.

\section{b. Hasil Reabilitas}

Untuk pengukuran hasil kuesioer pengabdian masyarakat dengan menggunakan pengukuran Reliabilitas Tes Tunggal (Internal Consistency Reliability). Maka dihasilkan seperti Tabel 2

Tabel 2. Hasil Pengukuran Reabilitas

\begin{tabular}{rc} 
t-hitung & 0,930535 \\
\hline t-tabel & 0,39607 \\
\hline alpha & 0,05 \\
\hline Jumlah Responden & 23 \\
\hline
\end{tabular}
mengenai Pemanfaatan Market Place Dalam Menunjang Pemasaran Produk. Mengembangkan potensi diri dikalangan peserta. Membangun kerja sama dan hubungan sosial yang baik antar peserta dengan peserta itu sendiri, peserta dengan kami, dan dengan Pemanfaatan Market Place Dalam Menunjang Pemasaran Produk. Berbagi ilmu pengetahuan untuk Komunitas Mersi Fans Club merupakan langkah penting untuk menyebar luaskan ilmu pengetahuan khususnya materi Pemanfaatan Market Place Dalam Menunjang Pemasaran Produk.

\section{UCAPAN TERIMAKASIH}

1. Komunitas Mersi Fans Club

2. Anggota atau tim yang berpartisipasi

Berdasarkan Tabel 2 diperoleh nilai $\mathrm{r}$ hitung $=0,930535>r$ tabel $=0,39607$, maka pertanyaanpertanyaan yang digunakan dalam penelitian tersebut reliabel.

Kegiatan pelatihan ini dianggap sangat bermanfaat bagi peserta karena menambah dan memperluas wawasan pengetahuan para peserta di bidang teknologi informasi. Dan juga menambah keterampilan yang dapat diterapkan dan dimanfaatkan langsung oleh para peserta dalam meningkatkan kualitas diri. Pemahaman peserta terlihat pada saat diskusi dan tanya jawab peserta dilakukan, para peserta mampu menyerap dan memahami materi yang disampaikan, terutama diskusi tentang bagaimana menjual barang pada marketplace. Pelatihan ini sangat diapresiasi oleh peserta Komunitas Mersi Fans Club dilihat dari antusias dan keaktifannya peserta dalam bertanya dan mengikuti pelatihan ini. Pada saat pembelajaran pun banyak para peserta yang antusias dalam bertanya tentang materi yang disampaikan oleh tutor. yang diberikan kepada peserta dimana bertujuan untuk mengukur kemampuan para peserta akan materi yang telah diberikan. Kegiatan berjalan lancar sampai akhir acara dan setiap tatap muka ditutup dengan

\section{DAFTAR REFERENSI}

[1] A. R. Priambodo, "PBB: Pandemi Covid-19 Munculkan Krisis Kesehatan Mental Global," suara.com, Jakarta, p. Health, 15May-2020.

[2] E. U. Nainggolan, "Kebijakan Fiskal dan Moneter Mengadapi Dampak Covid-19," djkn.kemenkeu.go.id, 2020. [Online]. Available:

https://www.djkn.kemenkeu.go.id/artikel/ baca/13017/Kebijakan-Fiskal-dan-

Moneter-Mengadapi-Dampak-Covid-

19.html.

[3] F. Pratama, "Solusi Jitu hadapi Dampak Sosial Virus Corona (covid-19)," puspensos.kemsos.go.id, 2020. [Online]. Available:

https://puspensos.kemsos.go.id/en/Publik asi/topic/659.

[4] Ekarina, "Strategi Mendorong UMKM Daerah Go-Online di Tengah Pandemi," katadata.co.id, Jakarta, p. Nasional, 03-Sep2020.

[5] Ina, "20 Macam Macam Metode Pembelajaran Lengkap," 
dosenpsikologi.com, 2018. [Online].

Available:

https://dosenpsikologi.com/macam-

macam-metode-pembelajaran.

[6] D. D. Unaradjan, Metode Penelitian Kuantitatif, 1st ed. Jakarta: Penerbit Unika Atma Jaya, 2019.

[7] M. Pane, A., \& Darwis Dasopang, "Belajar Dan Pembelajaran.," FITRAHJurnal Kaji. Ilmu-Ilmu Keislam., vol. 3, no. 2, p. 333, 2017. 